\title{
Effects of Exchange Rate on Value-Added International Trade
}

\author{
Myoung Shik Choi \\ Department of Economics, Kyonggi University, Suwon-si, Korea,msc50355@kyonggi.ac.kr
}

\begin{abstract}
In this study, value-added perspective focuses on the role of exports within a bilateral trading partner in the process of global value chains with vertical specialization, which is one of the various innovations in the world economy. Theoretically, we determine a proper model to connect both the value-added exports (Hummels et al. 1999; Johnson \& Noguera 2012; Koopman et al. 2010; Koopman and Wei 2014; UNCTAD 2013) and the changes in value-added exchange rates (Bems \& Johnson 2012, 2015; Patel et al. 2014; Yang et al. 2014). Then, based on their relationships, we investigate the value-added effects of exchange rate changes on international trade. Empirically, we adopt the calculating methods of using the value-added trade statistics (TiVA) developed by OECD-WTO. In particular, proper time series econometric models are tested for the United States of America and South Korea. We find that increase in foreign income increases the value-added exports, and increase in domestic income increases the value-added imports, but that currency appreciation decreases the value-added exports in Korea while currency appreciation increases the value-added exports in the US. We would judge that the export competitiveness relies on the currency devaluation in Korea but the domestic industry/economic growth in the US. Also, the value-added exports to gross exports are higher in Korea than the ones in the US as using more the global value chains. This will contribute to mitigate the global imbalances and exchange rate conflicts.
\end{abstract}

KEYWORDS: Exchange Rate, Global Value Chain, International Trade, Value-Added Exports

JEL Classification: F01, F40, F41, F62

\section{Introduction}

In the value-added perspective, we focus on the role of exports within a bilateral trading partner in the process of global value chains with vertical specialization, which is one of the various innovations in the world economy.

\section{Objectives}

Identify the phenomenon of trade balance with the target countries to draw implications of export structure. The purpose of this study is to investigate the effect of the exchange rate on international trade in a value-added framework. Trade in value-added describes an approach used to estimate the sources of value that are added to produce goods and services as global value chains expand.

\section{Methodology}

Theoretically, determine a proper model to connect both the value-added exports (Hummels et al. 1999; Johnson \& Noguera 2012; Koopman et al. 2010; Koopman and Wei 2014; UNCTAD 2013) and the changes in value-added exchange rates (Bems \& Johnson 2012, 2015; Patel et al. 2014; Yang et al. 2014), and then, based on their relationships, investigate the value-added impact of exchange rate on both exports and trade imbalance. Empirically, adopt the calculating methods of the value-added trade database (TiVA) of OECD-WTO. And bilateral time series models are tested for the United States and Korea.

\section{Expected findings \& policy implications}

We would judge the international trade by using value-added measures and then measure the effect of exchange rate on it. In particular, it will help anticipate the trade deficits and prevent them. So, this will contribute in mitigating the global imbalances and exchange rate conflicts. 


\section{Background for Conceptual model}

Figure 1 presents the methodology for effect of exchange rate on international trade in the valueadded perspective. The conceptual model in this methodology focuses on the role of the valueadded exports.

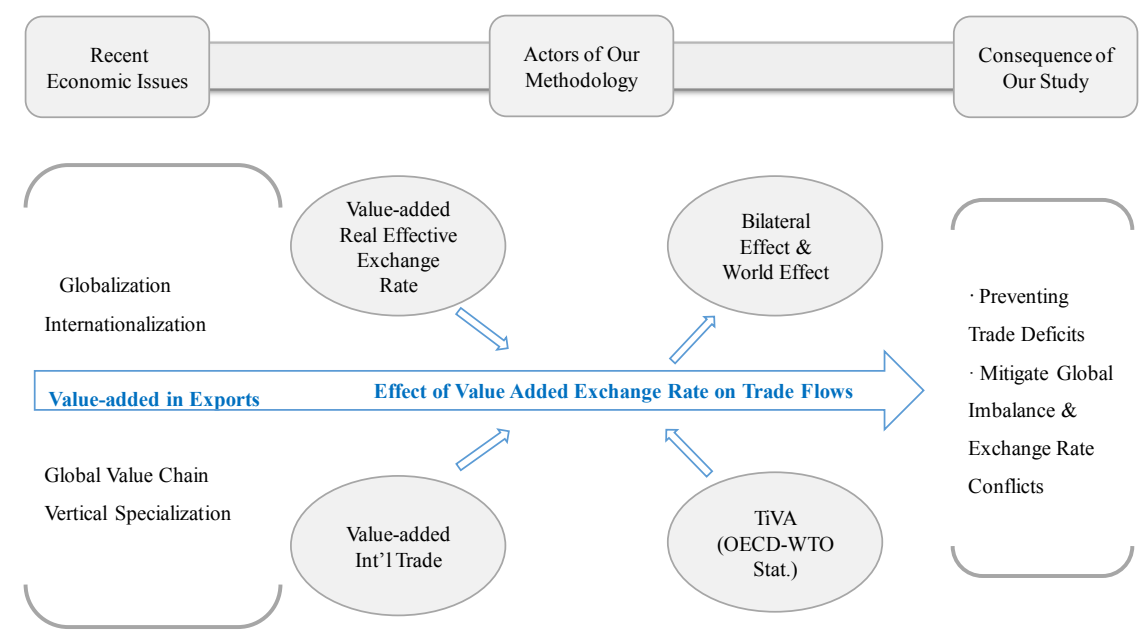

In this study, value-added perspective focuses on the role of exports within a bilateral trading partner in processes of global value chains with vertical specialization, which is one of various innovations in the world economy.

Figure 1. Methodology for Effect of Exchange Rate on TiVA

Table 1 indicates the dependence on external economies during the 2000s. Overall, trade to GDP ratios has increased in South Korea and the USA. However, 'export \& import (trade) to GDP ratio' is similar to 'value-added trade to GDP ratio' in the United States, but 'value-added trade to GDP ratio' represents about half of 'trade to GDP ratio' in Korea.

Table 1. Value-Added Trade to GDP Ratio in 2000s

\begin{tabular}{|c|c|c|c|c|}
\hline \multirow{2}{*}{ Year } & \multicolumn{2}{|c|}{ Korea } & \multicolumn{2}{c|}{ USA } \\
\cline { 2 - 5 } & $\begin{array}{l}\text { Export \& Import to } \\
\text { GDP (Trade Balance } \\
\text { to GDP) }\end{array}$ & $\begin{array}{l}\text { Value-Added } \\
\text { Export \& Import } \\
\text { to GDP }\end{array}$ & $\begin{array}{l}\text { Export \& Import to } \\
\text { GDP (Trade Balance } \\
\text { to GDP) }\end{array}$ & $\begin{array}{l}\text { Value-Added } \\
\text { Export \& Import } \\
\text { to GDP }\end{array}$ \\
\hline 2000 & $0.704(0.026)$ & 0.482 & $0.237(-0.038)$ & 0.192 \\
\hline 2001 & $0.654(0.021)$ & 0.457 & $0.217(-0.035)$ & 0.179 \\
\hline 2002 & $0.611(0.013)$ & 0.436 & $0.210(-0.039)$ & 0.175 \\
\hline 2003 & $0.647(0.021)$ & 0.436 & $0.213(-0.044)$ & 0.178 \\
\hline 2004 & $0.731(0.039)$ & 0.475 & $0.230(-0.051)$ & 0.192 \\
\hline 2005 & $0.712(0.025)$ & 0.462 & $0.239(-0.056)$ & 0.202 \\
\hline 2006 & $0.732(0.013)$ & 0.469 & $0.252(-0.056)$ & 0.210 \\
\hline 2007 & $0.768(0.014)$ & 0.484 & $0.262(-0.050)$ & 0.218 \\
\hline 2008 & $0.993(-0.011)$ & 0.576 & $0.281(-0.049)$ & 0.230 \\
\hline 2009 & $0.883(0.034)$ & 0.533 & $0.230(-0.028)$ & 0.194 \\
\hline 2010 & $0.943(0.023)$ & 0.556 & $0.260(-0.035)$ & 0.215 \\
\hline 2011 & $1.017(0.018)$ & 0.578 & $0.283(-0.037)$ & 0.232 \\
\hline 2012 & $1.029(0.028)$ & 0.578 & $0.289(-0.035)$ & 0.241 \\
\hline 2013 & $0.960(0.050)$ & 0.554 & $0.285(-0.031)$ & 0.239 \\
\hline 2014 & $0.891(0.053)$ & 0.526 & $0.286(-0.030)$ & 0.239 \\
\hline
\end{tabular}


Table 2 reports that South Korea's exports to the US are about $11 \%$ of total exports during the 2010s, and the US's exports to Korea are about 3\% of total exports. In particular, the value-added portions among Korea's exports to the US are about $90 \%$, but the value-added portions among the US's exports to Korea are about 70\% while Korea's value-added exports to the US continue to be in a surplus. This indicates that a share of domestic value-added to meet foreign final demand in Korea is bigger than in the US. According to TiVA indicators of OECD (2015), 'foreign final demand' excludes any value-added that may be embodied in inventories, electricity, gas \& water supply, and construction sectors.

Additionally, the domestic value-added in foreign final demand presents the direct and upstream value-added exported by the country's manufacturing sector, and it can be considered as a measure of industry export orientation. The larger countries highly integrated within global value chains, the lower export orientation rates are.

Table 2. Bilateral Trade Balance between USA and Korea in 2000s

\begin{tabular}{|c|c|c|c|c|c|c|}
\hline \multirow[t]{3}{*}{ Year } & \multicolumn{3}{|c|}{ Korea } & \multicolumn{3}{|c|}{ USA } \\
\hline & \multicolumn{2}{|c|}{ Export to USA } & \multirow{2}{*}{$\begin{array}{l}\text { Value-added } \\
\text { Trade Balance }\end{array}$} & \multicolumn{2}{|c|}{ Export to USA } & \multirow{2}{*}{$\begin{array}{l}\text { Value-added } \\
\text { Trade Balance }\end{array}$} \\
\hline & $\mathrm{USX} / \mathrm{X}$ & USXV/USX & & $\mathrm{KRX} / \mathrm{X}$ & KRXV/KRX & \\
\hline 2000 & 0.243 & 0.828 & 14.79 & 0.036 & 0.715 & -14.79 \\
\hline 2001 & 0.241 & 0.854 & 13.95 & 0.031 & 0.759 & -13.95 \\
\hline 2002 & 0.226 & 0.915 & 14.89 & 0.034 & 0.770 & -14.89 \\
\hline 2003 & 0.198 & 0.914 & 16.38 & 0.035 & 0.727 & -16.38 \\
\hline 2004 & 0.189 & 0.912 & 23.23 & 0.036 & 0.702 & -23.23 \\
\hline 2005 & 0.159 & 0.975 & 20.35 & 0.036 & 0.711 & -20.35 \\
\hline 2006 & 0.146 & 1.002 & 18.51 & 0.037 & 0.723 & -18.51 \\
\hline 2007 & 0.139 & 0.955 & 18.73 & 0.036 & 0.720 & -18.73 \\
\hline 2008 & 0.123 & 0.861 & 12.59 & 0.033 & 0.694 & -12.59 \\
\hline 2009 & 0.119 & 0.925 & 12.11 & 0.032 & 0.711 & -12.11 \\
\hline 2010 & 0.114 & 0.914 & 11.99 & 0.037 & 0.700 & -11.99 \\
\hline 2011 & 0.111 & 0.871 & 15.02 & 0.034 & 0.692 & -15.02 \\
\hline 2012 & 0.115 & 0.866 & 18.52 & 0.033 & 0.734 & -14.87 \\
\hline 2013 & 0.109 & 0.9108 & 19.11 & 0.031 & 0.757 & -15.52 \\
\hline 2014 & 0.111 & 0.924 & 20.59 & 0.030 & 0.758 & -16.75 \\
\hline
\end{tabular}

** $\mathrm{X}=$ gross exports of Korea or USA, USX=exports to USA of Korea, USXV=value added exports to USA of Korea, $\mathrm{KRX}=$ exports to Korea of USA, KRXV=value added exports to Korea of USA, Value-added Trade Balance=bilateral value-added trade balance between USA \& Korea (unit=billion USD).

Table 3 represents the real effective exchange rate calculated mainly by BIS'(2006)s narrow method and the value-added real effective exchange rate during the 2000s. Real effective exchange rate and value-added real effective exchange rate are almost similar but seem to be slightly different in the case of the US and Korea. The value-added real effective exchange rate that is computed by using GDP deflator and value-added exports and imports, will be applied to the value-added trade models. 
Table 3. Value-Added Real Effective Exchange Rate in 2000s

\begin{tabular}{|c|c|c|c|c|}
\hline \multirow{2}{*}{ Year } & \multicolumn{2}{|c|}{ Korea } & \multicolumn{2}{c|}{ USA } \\
\cline { 2 - 5 } & REER Index & VA REER Index & REER Index & VA REER Index \\
\hline 2000 & 0.997 & 0.961 & 1.289 & 1.322 \\
\hline 2001 & 1.012 & 0.986 & 1.261 & 1.292 \\
\hline 2002 & 1.017 & 0.989 & 1.212 & 1.242 \\
\hline 2003 & 1.009 & 0.991 & 1.098 & 1.112 \\
\hline 2004 & 1.003 & 0.994 & 1.049 & 1.061 \\
\hline 2005 & 0.980 & 0.985 & 1.058 & 1.082 \\
\hline 2006 & 0.979 & 0.985 & 1.033 & 1.052 \\
\hline 2007 & 0.993 & 0.989 & 0.954 & 0.958 \\
\hline 2008 & 1.023 & 1.017 & 0.954 & 0.933 \\
\hline 2009 & 1.045 & 1.037 & 0.948 & 0.936 \\
\hline 2010 & 1.0 & 1.0 & 1.0 & 1.0 \\
\hline 2011 & 1.001 & 0.998 & 0.970 & 0.970 \\
\hline 2012 & 1.014 & 1.003 & 0.997 & 1.001 \\
\hline 2013 & 1.019 & 1.006 & 0.966 & 0.971 \\
\hline 2014 & 1.010 & 0.999 & 1.012 & 1.013 \\
\hline
\end{tabular}

** REER=Real Effective Exchange Rate, VA REER=Value-added Real Effective Exchange Rate. And base year=2010.

\section{Empirical Testing}

This section reports econometric procedures and summarizes our empirical findings. We obtained the yearly data of OECD for international trade statistic and of FRED (Federal Reserve Economic Data-St. Louis Fed) for other economic statistics. To estimate the impact of exchange rate on exports or trade balance, we specify the set of dependent variables and explanatory variables for the period between 1995 and 2014. No logarithmic transformation is adopted because of negative net exports.

First, all single variables are tested for unit roots to check out the long run equilibrium in the stationarity-testing stage. The results by using the Augmented Dickey-Fuller tests of Dickey and Fuller (1979) are presented in Table 4. They suggest that all variables are found to be non-stationary and first-difference stationary.

Table 4. Results of ADF Tests for Unit Roots

\begin{tabular}{|l|l|l|c|c|l|l|l|l|l|l|}
\hline & \multicolumn{4}{|l}{ Level Variables } & \multicolumn{4}{|c|}{ First Difference Variables } \\
\cline { 2 - 11 } & $\mathbf{X}$ & $\mathbf{M}$ & $\mathbf{R}$ & $\mathbf{Y}$ & $\mathbf{W Y}$ & $\mathbf{X}$ & $\mathbf{M}$ & $\mathbf{R}$ & $\mathbf{Y}$ & WY \\
\hline Korea & 0.89 & -0.33 & -2.75 & 0.33 & 0.99 & $-3.81^{*}$ & $-4.52^{*}$ & $-4.49^{*}$ & $-3.52^{*}$ & $-3.41^{*}$ \\
\hline USA & 1.54 & -0.69 & -1.08 & -0.05 & 0.99 & $-3.31^{*}$ & $-4.78^{*}$ & $-3.42^{*}$ & -2.69 & -3.41 \\
\hline
\end{tabular}

Note: $\mathrm{X}=$ value-added exports, $\mathrm{M}=$ value-added imports, $\mathrm{R}=$ value-added real effective exchange rate, $\mathrm{Y}=\mathrm{GDP}, \mathrm{WY}=\mathrm{world}$ GDP. Note: * represents significant meaning at the 5\% level (critical value $=-3.02$ ) in the model with intercept. In addition, $10 \%$ level (critical value $=-2.65$ ).

Second, we use the time series integrated of order one in the long run equilibrium-testing stage. The results by using the cointegration procedure of Engle and Granger (1987) are presented in Table 5 below. They suggest that the null hypothesis of no cointegration is not rejected. 
Table 5. Results of Engle-Granger Tests for Cointegration

\begin{tabular}{|c|c|c|c|c|c|c|}
\hline & \multicolumn{3}{|c|}{ Level Variables (Null Statistic) } & \multicolumn{3}{|c|}{$\begin{array}{l}\text { First Difference Variables (Null } \\
\text { Statistic) }\end{array}$} \\
\hline & $\begin{array}{l}X=f(R, \\
\text { NY) }\end{array}$ & $\begin{array}{l}\mathbf{M}=\mathbf{f}(\mathbf{R}, \\
\mathbf{Y})\end{array}$ & $\begin{array}{l}\text { TB=f(R, Y, } \\
\text { NY) }\end{array}$ & $\begin{array}{l}d X=f(d R, \\
d N Y)\end{array}$ & $\begin{array}{l}d M=f(d R, \\
d Y)\end{array}$ & $\begin{array}{l}d T B=f(d R, \\
d Y, d N Y)\end{array}$ \\
\hline Korea & -2.84 & -2.69 & -2.02 & $-4.83 *$ & $-5.50 *$ & -3.95 \\
\hline USA & -2.48 & -3.97 & -3.79 & -3.34 & $-4.69^{*}$ & -2.75 \\
\hline
\end{tabular}

Note: $\mathrm{NY}=\mathrm{WY}-\mathrm{Y}, \mathrm{TB}=\mathrm{X}-\mathrm{M}, \mathrm{d}=$ first-difference, $\mathrm{f}(\mathrm{)}=$ function notation. Note: $*$ represents significant meaning at the $5 \%$ level (critical value $=-4.75 \sim-4.19$ ) in the model with intercept and trend. In addition, 5\% level (critical value=-5.2 -4.69) for TB.

Third, we estimate the first-difference equation for trade models because the variables within the model do not cointegrate. The results in Table 6 indicate the change effects of the real effective exchange rate on the international trade in value-added perspective.

Table 6.1. Results of Long-run Exchange Rate Effects on Gross Trade in Value-added

\begin{tabular}{|c|c|c|c|}
\hline & $d X=f(d R, d N Y)$ & $\mathbf{d M}=\mathbf{f}(\mathbf{d R}, \mathbf{d Y})$ & $d T B=f(d R, d Y, d N Y)$ \\
\hline Korea & $\begin{array}{l}\mathrm{dX}=2.72-271.3 \mathrm{dR}+\mathbf{0 . 0 0 6} \mathrm{dNY} \\
(0.44)(0.01)^{*}(0.0)^{*}\end{array}$ & $\begin{array}{l}\mathrm{dM}=2.52-169.4 \mathrm{dR}+\mathbf{0 . 2 1} \mathrm{dY} \\
(0.76)(0.66)(0.06)^{*}\end{array}$ & $\begin{array}{l}\mathrm{dTB}=3.09+744.9 \mathrm{dR}+0.15 \mathrm{dY}- \\
\mathbf{0 . 0 0 3} \mathrm{dNY} \\
\quad(0.59)(0.02)^{*}(0.10)(0.04)\end{array}$ \\
\hline USA & $\begin{array}{l}d X=12.6+542.6 d R+\mathbf{0 . 0 2} d N Y \\
(0.44)(0.03)^{*}(0.0)^{*}\end{array}$ & $\begin{array}{l}\mathrm{dM}=-178+64.3 \mathrm{dR}+\mathbf{0 . 5 1} \mathrm{dY} \\
(0.00)(0.87)(0.00)^{*}\end{array}$ & $\begin{array}{l}\mathrm{dTB}=132-38.4 \mathrm{dR}-\mathbf{0 . 2 5} \mathrm{dY}-0.01 \mathrm{dNY} \\
(0.01)(0.92)(0.01) *(0.42)\end{array}$ \\
\hline
\end{tabular}

Note: the values in the parentheses are p-values for explanatory variables respectively. ${ }^{*}$ indicates significant meaning at the $5 \%$ level. Note: the unit for $\mathrm{X}, \mathrm{M}, \mathrm{TB}$ and $\mathrm{Y}$ is billions.

Table 6.1. reports that currency appreciation decreases the value-added exports, and increase in foreign income increases the value-added exports while increase in domestic income increases the value-added imports in the case of Korea. On the contrary, currency appreciation increases the value added exports, and increase in foreign income increases the value-added exports while increase in domestic income increases the value-added imports in the case of the US.

Table 6.2. Results of Long-run Exchange Rate Effects on Bilateral Trade in Value-added

\begin{tabular}{|l|l|l|c|}
\hline & \multicolumn{1}{|c|}{$\mathbf{d X}=\mathbf{f}(\mathbf{d R}, \mathbf{d F Y})$} & $\mathbf{d M}=\mathbf{f}(\mathbf{d R}, \mathbf{d Y})$ & $\mathbf{d T B}=\mathbf{f}(\mathbf{d R}, \mathbf{d Y}, \mathbf{d F Y})$ \\
\hline Korea & $\mathrm{d} \mathrm{X}=\mathbf{- 3 . 2}-\mathbf{5 1 . 9} \mathrm{dR}+\mathbf{0 . 0 1} \mathrm{dFY}$ & $\mathrm{dM}=0.57-78.64 \mathrm{dR}+\mathbf{0 . 0 2} \mathrm{dY}$ & $\mathrm{dTB}=-2.2+94.0 \mathrm{dR}+0.01 \mathrm{~d} Y+0.01 \mathrm{dFY}$ \\
& $(0.08)^{\wedge}(0.08)^{\wedge}(0.00)^{*}$ & $(0.45)(0.13)(0.04)^{*}$ & $(0.30)(0.19)(0.76)(0.34)$ \\
\hline USA & $\mathrm{dX}=-0.22+\mathbf{2 0 . 9} \mathrm{dR}+\mathbf{0 . 0 4} \mathrm{dFY}$ & $\mathrm{dM}=-4.12+13.5 \mathrm{dR}+\mathbf{0 . 0 1 3 \mathrm { dY }}$ & $\mathrm{dTB}=-2.2+14.1 \mathrm{dR}-0.01 \mathrm{~d} \mathrm{Y}+0.02 \mathrm{dFY}$ \\
& $(0.97)(0.05)^{*}(0.00)^{*}$ & $(0.03)(0.37)(0.00)^{*}$ & $(0.32)(0.83)(0.13)(0.16)$ \\
\hline
\end{tabular}

Note:the values in the parentheses are p-values for explanatory variables respectively. * indicates significant meaning at the $5 \%$ level.^ indicates significant meaning at the $10 \%$ level.FY=foreign counterpart GDP.

Table 6.2. reports that currency appreciation decreases the value-added exports to the US, and increase in the US income increases the value-added exports to the US while increase in domestic income increases the value-added imports from the US in the case of Korea. On the contrary, currency appreciation increases the value-added exports to Korea, and increase in Korean income increases the 
value-added exports to Korea while increase in domestic income increases the value-added imports from Korea in the case of the US.

\section{Conclusion}

This paper investigates the value-added effects of the real effective exchange rate on international trade using a set of the US and Korea. We employ traditional trade models and apply the valueadded measures to examine their relationship.

The long run effects on gross trade in value-added show that increase in foreign income increases the value-added exports, and increase in domestic income increases the value-added imports in the US and Korea. However, that currency appreciation decreases the value-added exports in Korea while currency appreciation increases the value-added exports in the US. And the long run effects in bilateral trade in value-added show the same results.

We would judge that the export competitiveness relies on the currency devaluation in Korea but the domestic industry/economic growth in the US. Also, the value-added exports to gross exports are higher in Korea than them in the US as using more the global value chains. This will contribute to mitigate the global imbalances and exchange rate conflicts.

The topic of this paper is highly relevant given the fact that recent open economies have resorted to the global value chains and value-added international trade as well as the exchange rate as an additional instrument of monetary policy. Thus, policy makers may have to consider our suggestions.

\section{References}

Bems, R. and R. Johnson. 2012."Value-Added Exchange Rates." NBER WP 18498.

Bems, R. and R. Johnson. 2015. "Demand for Value Added and Value-Added Exchange Rates." International Monetary Fund (IMF) WP 15/199.

BIS, “The New BIS Effective Exchange Rate Indices.” 2006. BIS Quarterly Review pp. 51-65.

Dickey, D. A. and W.A. Fuller. 1979. "Distribution of the Estimators for Autoregressive Time Series with a Unit Root." Journal of American Statistical Association 74 (366): 427-431.

Engle, R.F. and C.W.J. Granger. 1987. "Cointegration and Error Correction: Representation, Estimation and Testing." Econometrica 55 (2): 1251-1276.

Hummels, D., J. Ishii and K. Yi. 1999. "The Nature and Growth of Vertical Specialization in World Trade.” A Revision \& extension of "The Growth of World Trade" by Ishii \& Yi (1997).

Johnson, R. \& G. Noguera. 2012. “Accounting for Intermediates: Production Sharing and Trade in Value Added.” Journal of International Economics 86 (2): 224-236.

Koopman, R., Powers, W., Wang, Z. and S. Wei. 2010. "Give Credit to Where Credit is Due: Tracing Value Added in Global Production Chains." NBER, WP 16426.

Koopman, R., Z. Wang, and S. Wei. 2014. "Tracing Value-Added and Double Counting." American Economic Review 104 (2): 459-94.

OECD. 2015. "Trade in Value Added (TIVA) Indicators, Guide to Country Notes."

UNCTAD. 2013. Global Value Chains and Development. Retrieve from http://unctad.org/.

Yang, P., X. Li, and Q. Xu. 2014. "Value-Added Effective Exchange Rates for China: Facts and Implications." China External Environment Monitor. 